\title{
Problem Solving Ability and Communication Skill Through Problem-Based Learning Approach
}

\author{
Meifitri $^{1}$ \\ ${ }^{1}$ Universitas Negeri Bengkulu,Bengkulu,Indonesia,ه(email), meifitri89@gmail.com
}

\begin{abstract}
Problem-based learning (PBL) is a teaching method in which complex real-world problems are used as the vehicle to promote student learning of concepts and principles as opposed to direct presentation of facts and concepts. In addition to course-content, problem-based learning can promote the development of problemsolving ability and communication skill. Problem-solving skill help you determine the source of a problem and find an effective solution. This paper aims to discuss about the background of problem-based learning when implemented in the classroom, and how by applying the problem-based learning approach can improve the students' problem-solving ability and communication skill.
\end{abstract}

\section{Keywords: Problem-Based Learning, Problem Solving, Communication Skill}

\section{INTRODUCTION}

In the learning process sometimes students often have difficulty in solving problems or assignments given by the teacher. Problem solving is a person's ability to solve problems based on individual skills. Problem solving will be better when the individual experiences the problem. Unless and until one owns the problem, one cannot possibly solve the problem. Problem-based learning is an approach that involves no teaching, students learn by solving problems that are carefully constructed by the teacher according to the course syllabus assigned to them throughout the semester. Implementing the problem-based learning approach can train students to get used to solving problems encountered and also can train the students' communication skills. By using a problem-based learning approach, students do not merely receive information from the teacher, because in this case, the teacher as a motivator and facilitator directs students to be actively involved in the whole learning process by beginning with problems related to the concepts being studied.

\section{RESULT AND DISCUSSION}

\section{Problem-Based Learning}

Problem-based learning is a learning approach that uses real-world problems as a context for students to learn about critical thinking and problem solving abilities, as well as to obtain essential knowledge and concepts from subject matter. Similarly, Bound and Felleti in Saptono (2003) argue that "Problem-based learning is a way of constructing and teaching course using problem as a stimulus and focus on student activity".

In addition, Yew (2009:11) affirms that "Problembased learning is a learning approach based on the context of a situation that seeks to create a learning environment with meaningful problems, so that, problem solving learning is able to build mental models and ideas with colleagues collaboratively and develop students' skills for independent learning".

Problem-based learning is one pedagogical approach that might fit in your teaching toolbox. Problem-based learning is a student-centered, inquiry-based instructional model in which learners engage with an authentic, illstructured problem that requires further research (Jonassen $\&$ Hung, 2008).

While according to Wadani (2014), states that "problem-based learning is a learning method through which the learners gain and develop upper-level skills such as problem solving and critical thinking while eliciting information from personal real-life experiences and acquiring determinate knowledge about their learning". It is a method utilizing a constructivist approach, with which students strive to solve daily issues in collaborative environments.

Copland (2001:3) who teaches Problem-based learning courses in the Prospective Principals Program in the School of Education at Stanford says, "A key thing in making (PBL) successful is the amount of time and energy that goes into the creation of the project. Finding a problem that really means something to the participants is absolutely critical".

In further, Arends (1997:156) explains that "Problembased learning is an approach that used in promoting higher-level thinking in problem-oriented situations, including learning how to learn". According to Arends, Problem-based learning is one of the learning models that used to improve the level of higher thinking oriented to the problems, including learning. The problems are faced by the students are the form of learning material concepts, so that with these problems it can stimulate students' higher 
thinking processes in solving problems. Initial point is to get or integrate new knowledge.

In short, it can be inferred that problem-based learning is a learning model that involves students to solve the problems through stages of the scientific method so that, the students can learn the knowledge related to the problem and at the same time have the skills to solve the problems. Problem-based learning is a learning process that is the starting point of learning based on problems in real life and then from this problem students are stimulated to learn this problem based on new knowledge and experience.

\section{Implementation of Problem-Based Learning}

Implementation of Problem-based learning in the classroom proposed by several experts;

The first, Abdalla and Gaffar (2011:15) state that there are three steps in implementing Problem-based learning in teaching learning process:

\section{First step of Problem-based learning}

The purpose of this step is to discuss the objectives of Problem-based learning which include challenging students' knowledge and experience to solve the problem given to them. In this phase, the group has to set up their roles and responsibilities in group discussion including a leader of the group, secretary and also member of the group. The duration of this step should be 1-2 hours. After the first session of Problem-based learning, students will have several days to study individually to manage the assignments given by the teacher.

2.Second step of Problem-based learning

The duration of this step must be 1-2 hours. The purpose of this step is to share what students have learned individually to solve problems. Meanwhile, the aims of this step are to train them to be active thinkers, cooperate with others, take responsibility for the tasks assigned to them, learn how to inform others and get early feedback about the results of the learning process.

3.Third step of Problem-based learning

The duration of the last step should be 1-2 hours. The aim is to create a discussion forum where the students can ask the experts about the problems given previously. They must share the results of group discussions in front of other groups to get feedback from them.

The second one is proposed by Tan (2003), and the stages are:

\section{Meeting the problem}

At this meeting, the problem will stimulate the learning process to expand the realistic context that students might encounter in the future. Activities to be carried out in this first meeting includes: developing collegiality, reading individually, reflection and inquiry, commitment to group roles, brainstorming problems that might occur and commitment to discuss and analyze the problems encountered;

2. Problem analysis and learning issues

At this second meeting, at the previous meeting, students had conducted stimulus activities and analysis of the problem. At this meeting students are asked to work independently in their problems, seek information through various sources, identify problems then analyze learning and formulate learning objectives. At the end of the activity assignment of independent learning and peer teaching to students.;

3.Discovery and reporting

The activity that students do at this meeting is to report new information that they find. After sharing information with others, in a collaborative group of students practice communication skills through questions to find more information from each other;

4.Solution presentation and reflection

At this stage, students are asked to better understand what they have done by paraphrasing the knowledge they can based on their abilities individually. When they face doubts about the knowledge they can then they can ask the tutor to help explain;

5.Overview, integration and evaluation

Review, evaluation and integration are a unity in the learning process. In this activity, students are motivated to criticize their learning resources, both regarding the value reliability and the benefits of these learning resources in the future. Students reflect on the new knowledge they have learned as a result of the problem then the tutor helps them how to summarize and integrate the main principles and concepts from their learning outcomes. And finally, group members evaluate their activities in terms of being problem solvers and becoming independent learners.

\section{Characteristics of PBL}

Problem-based learning is one of the learning models that are used to improve the level of high thinking oriented to the problem that has several characteristics. These characteristics specify by some experts as follows. First, Arends (1997:157) summarizes that there are five specific features of Problem-based learning, namely:

1. Driving questions or problems

Driving on Problem-based learning organizes lessons around questions or problems that are socially important rather than organizing on certain academic principles. Problem-based learning is addressed to a real situation, which avoids simple answers, in which there are various solutions with various interests,

2. Interdisciplinary focus

Problem-based learning is chosen for problems involving several disciplines,

3. Authentic investigation

Problem-based learning requires following authentic investigations, looking for real solutions to real problems. Students must analyze and formulate the problems, develop hypotheses and make predictions, collect and analyze the information,

4. Product of artifacts and exhibit

The students are required to arrange a product in an artifact and exhibit that explains or shows the solution. This product is prepared by students to demonstrate to other students, 


\section{Collaboration}

Work with other people mostly in pairs or small groups, and the development of thinking skills and social skills.

Second, Rayne and Symons (2005: 6) state that there are some components in Problem-based learning which will be explained as follows:

1. Group work, students work together in small groups and provide a framework in which students can test and develop their level of understanding of the material,

2. Problem solving, the problems given in a Problem-based learning environment are often daily problem means that they face it every time in their life that need enquiry and critical analysis to solve it,

3. Discovering new knowledge, in order to find a meaningful solution, students will have to seek new knowledge,

4. Based on the real world, the main emphasis is to encourage students to start thinking like an expert early on in their careers, thereby easing them to solve their daily problem in their real life.

Third, Muslimin Ibrahim (2000:7) lists six characteristics of Problem-based learning:

1. Learning begins with a problem,

2. Ensure that the problem is related to the real world of the students,

3. Organizing lessons around problems, not about disciplines,

4. Give great responsibility to the students in forming and running directly their own learning process,

5. Use a small group,

6. Demand students to demonstrate what they have learned in the form of products or performance.

From the opinions of the experts above, it can be concluded that Problem-based learning is a learning approach that uses the real-world problems, which helps students to be able to learn independently and be able to work together with other students in a small group so that it can improve the students' communication.

\section{Problem Solving Abilities through PBL}

When employers talk about problem-solving skills, they are often referring to the ability to handle difficult or unexpected situations in the workplace as well as complex business challenges. Organizations rely on people who can assess both kinds of situations and calmly identify solutions. Problem-solving skills are traits that enable you to do that. While problem-solving skills are valued by employers, they are also highly useful in other areas of life like relationship building and decision making.

Addalla and Gaffar (2011:1) explain that "Problembased learning education strategy is characterized by using patient's problem as a motive for students learning, to acquire knowledge of basic and clinical sciences related to that problem and acquire problem solving skills".

Consistent with this understanding of what is meant by a problem, Mayer (1990) defines problem solving as cognitive processing directed at transforming a given situation into a goal situation when no obvious method of solution is available.

In addition, Schmidt (1983) also suggests that in problem based learning, prior learning activities can help students in problem solving. Group members may activate their prior knowledge and accumulate new knowledge to identify and solve the problems.

Similarly, Norman \& Schmidt (1992) add in group discussion, members' contributions of elaborated knowledge are valuable for they formulate creative ideas and they facilitate the discovery of possible solutions.

A problem-based learning approach can improve students' ability to solve problems. In applying the Problem-based learning approach, the teacher gives students orientation about problems and motivates the students to engage in problem solving activities. The orientation of the problem is the teacher gives a problem according to the topic to be discussed. Students are expected to be able to solve the problem in a group.

\section{Communication Skills through PBL}

Communication skills are abilities that used when giving and receiving different kinds of information. Some examples include communicating ideas, feelings or what's happening around you. Communication skills involve listening, speaking, observing and empathizing. It is also helpful to understand the differences in how to communicate through face-to-face interactions, phone conversations, and digital communications.

Problem-based learning helps students develop advanced cognitive abilities such as creative thinking, problem solving and communication skills (Major, 2001).

In further, Watson in Duch, Groh \& Allen (2001) argue that "in the learning process of Problem-based learning, the students work with classmates to solve complex and authentic problems that help develop content knowledge as well as problem solving, reasoning, communication, and self-assessment skills".

Nilson (2010) lists the following learning outcomes that are associated with Problem-based learning. Some skills that will be obtained by students from applying problem-based learning and two of them are communication skills and problem solving abilities.

Problem-based learning is not only about problem solving, but instead it uses appropriate problems to increase cognition and reason. Group learning facilitates not only the learning of knowledge, but also some other desirable attributes such as communication skills, teamwork, problem solving, independent responsibility for learning, sharing information and respect for others. By applying the problem-based learning approach can also improve the students' communication skills, because problem-based learning focuses on students and they are required to be independent and share their knowledge in front of other students.

\section{CONCLUSION}

Many students experienced difficulties when studying, especially in terms of communicating and being 
independent to solve problems that are around them. In this case, not only students are required to learn a lot but the teacher as a facilitator or motivator in teaching and learning processes should understand and know what approaches should be applied to the students in the classroom so that, they are more motivated in learning. One of the current methods that can improve students' ability to solve problems and be able to communicate well is problem-based learning. Problem-based learning focuses on students to be more active and independent in the learning process.

\section{ACKNOWLEDGMENTS}

I am grateful to Allah SWT for the guidance and showing me the way in accomplishing this paper. I would like to express my special thanks of gratitude to Prof. Syafnil, MA, Ph.D. and Dr. Wisma Yunita, M.Pd., who has provided extraordinary comments, motivation, support and insight to improve the writing of this paper, without her help this manuscript would not be able to finish properly. Thanks to Graduate State University of Padang that organize the Eighth International Conference on Languages and Arts (ICLA-8) for giving me an opportunity to present my paper in this seminar.

\section{REFERENCES}

[1] Abdalla, Muhammed Elhasan \& Abdelrahim Mutwakel Gaffar. (2011). The Seven Steps of PBL implementation. KSA: Jazan University.

[2] Arends, Richard I. (1997). Classroom Instruction and Management. USA: the Mc.Graw-Hill Companies.

[3] Copland, Michael. (2001). Speaking of Teaching. Stanford University Newsletter on Teaching, Winter 2001,1(1).

[4] Duch, B. J., Groh, S. E, \& Allen, D. E. (Eds.). (2001). The Power of problem based.learning. Sterling,VA:Stylus.Retrievedfrom:http://citl.illinoi s.edu/citl101/teachinglearning/resources/teaching strategies/problem-based-learning

[5] Jonassen, D. H., \& Hung, W. (2008). All problems are not equal: Implications for problem-based learning. Interdisciplinary Journal of ProblemBased Learning, 2(2), 4.

[6] Major, C. (2001). Assessing The Effectiveness Of Problem Based Learning in Higher Education: Lessons From The Literature, Academic Exchange Quarterly, 5(1).

[7] Mayer, R.E. (1990). "Problem solving", in M. W. Eysenck (ed.), The Blackwell Dictionary of Cognitive Psychology, Basil Blackwell, Oxford, pp. 284-288.

[8] Muslimin Ibrahim. 2000. Pembelajaran Kooperatif. Surabaya: University Press.
[9] Nilson, L. B. (2010). Teaching at its best: A research-based resource for college instructors (2nd ed.). San Francisco, CA: Jossey-Bass.

[10] Norman, G. R. \& Schmidt, H. G. (1992). The Psychological Basis of Problem-Based Learning: A review of the evidence. Academic Medicine, 67 (9), 557-565.

[11]Rayne, Derek \& Sarah Symons. (2005). Possibilities: a Practices Guide to Problem Based Learning in Physics and Astronomy. UK. University of Hull.

[12] Schmidt, H. G. (1983). Problem-based learning: rationale and description. Medical Education $l$. Vol. 17: 11-16.

[13] Tan, Oon Seng. (2003). Problem-based learning innovation. Singapore: Thomson.

[14] Wadani, F., \& Khan, A.R. (2014). Problem-based learning in ophthalmology: A brief review. Oman Journal of Ophthalmology, 7(1).

[15] Yew, Elaine H. J. 2009. Process of Problem Based Learning. Singapore: Ruby Printing. pte ltd. 